\title{
The impact of macroprudential policy on financial stability in selected EU countries
}

\author{
EVA LORENČIČ, MSc \\ MEJRA FESTIĆ, Ph.D.*
}

Article $^{* *}$

JEL: E58, G28, E60, E44

https://doi.org/10.3326/pse.46.1.5

\footnotetext{
${ }^{*}$ The views and opinions expressed in this paper are solely those of the authors and do not in any way reflect the official policy, position or opinion of the Faculty of Economics and Business, University of Maribor or of Credit Suisse Group AG, Zurich, Switzerland. The authors would like to thank two anonymous reviewers for their valuable remarks and suggestions.

${ }^{* *}$ Received: March 5, 2021

Accepted: October 1, 2021
}

\section{Eva LORENČIČ}

Credit Suisse Group AG, Uetlibergstrasse 231, CH-8045 Zurich, Switzerland, and University of Maribor, Faculty of Economics and Business, Razlagova 14, 2000 Maribor, Slovenia e-mail: eva.lorencic@student.um.si, eva.lorencic@credit-suisse.com, eva.loren@gmail.com ORCiD: 0000-0003-1626-1398

\section{Mejra FESTIĆ}

University of Maribor, Faculty of Economics and Business, Razlagova 14, 2000 Maribor, Slovenia e-mail: mejra.festic@um.si ORCiD: 0000-0002-8574-8696 
Abstract

The aim of this paper is to examine the impact of selected macroprudential policy instruments on financial stability. We focus on six euro area economies (Belgium, Cyprus, Germany, Spain, Ireland and the Netherlands) over sixteen quarters (from 2015 Q1 to 2018 Q4) by using the research method of panel econometrics. The following three banking sector aggregate balance sheet variables exhibit the expected impact on credit growth and cyclical fluctuations of the economy: common equity tier one ratio, coverage ratio, and interconnectedness ratio. Moreover, common equity tier one ratio, loan-to-deposit ratio, and leverage ratio exhibit the expected impact on house price growth. Based on our empirical findings, a case can be made for the usage of carefully crafted macroprudential policy instruments that target selected financial and macroeconomic variables with the ultimate goal of attaining the stability of the financial system as a whole.

Keywords: macroprudential policy, macroprudential instruments, financial stability

\section{INTRODUCTION}

In this paper we investigate the impact of banking sector aggregate balance sheet variables influenced by macroprudential policy instruments on financial stability. Financial stability is defined as a condition in which the financial system, consisting of markets, financial intermediaries and market infrastructures, does not yield to the adverse impacts of shocks and financial imbalances. The financial systemwide distress is limited and financial intermediation process is not disrupted to such an extent that the real economy could be adversely affected (Borio, 2011; ECB, 2020). Financial stability requires that the financial system be resilient to external shocks as well as to shocks originating within the financial system (Galati and Moessner, 2011). The main costs of financial instability are manifested as output losses (Crockett, 2000). The formation of possible systemic risks in the financial system is monitored and countered through macroprudential policies. The first and foremost goal of macroprudential policy is to achieve and maintain financial stability by reducing systemic risk stemming from excessive procyclicality in the financial sector, from interconnections and other cross-sectional factors (ECB, 2020; Claessens, 2014). Evidence on the effectiveness of specific macroprudential tools is slowly starting to accumulate in the economics profession; however, there is still much to be done (Claessens, 2014). Our paper is a contribution to this field.

The aim of this paper is to empirically investigate the impact of six banking sector aggregate balance sheet variables influenced by macroprudential policy instruments (common equity tier 1 ratio (CET); loan-to-deposit ratio (LDR); nondeposit funding as percentage of total funding (NDF); leverage ratio (LR); interconnectedness ratio (INR); and coverage ratio (CR)) on financial stability (as measured by credit growth rate (CGR) and house price growth rate (HPGR)) and on cyclical fluctuations of the economy (as measured by the amplitude of the deviation of the actual economic growth rate from its long-run trend (DEG)) in six 
euro area countries (Belgium, Cyprus, Germany, Spain, Ireland and the Netherlands) over sixteen quarters (from 2015 Q1 (inclusive) to 2018 Q4 (inclusive)).

If our empirical results indicate that the selected macroprudential policy instruments do impact measures of financial stability in the predicted manner, a case can be made for the usage of carefully crafted macroprudential policy instruments that target selected financial and macroeconomic variables with the ultimate goal of attaining the stability of the financial system as a whole. This is very relevant for policymaking, since the rest of the existing economic policies (monetary, microprudential, fiscal, and structural) operate with a different toolkit and strive to achieve goals other than the stability of the financial system as a whole. As such, another policy - namely macroprudential policy - is required for the achievement of the stability of the financial system at large. Our research aims to corroborate or refute the statement that the usage of macroprudential policy instruments can stabilise the financial system.

While most papers investigating the impact of macroprudential policy instruments on financial stability rely on the usage of the loan-to-value (LTV) ratio and/or the countercyclical capital buffer $(\mathrm{CCyB})$ as explanatory variables, our paper is unique in that it employs a wider variety of macroprudential policy instruments. In particular, we use the following explanatory variables: common equity tier 1 ratio; loans to deposits ratio; non-deposit funding as percentage of total funding; leverage ratio; interconnectedness ratio; and coverage ratio for non-performing exposures. While most of the papers on the topic of macroprudential policy investigate the impact of changes in macroprudential policy instruments on only one or two dependent variables, we employ three different dependent variables: credit growth rate; house price growth rate; and the amplitude of the deviation of the actual economic growth rate from its long-run trend. This allows us to thoroughly examine the impact of changes in selected macroprudential policy instruments on financial stability and on cyclical fluctuations of the economy. As such, our paper imparts an added value to the existing body of literature.

\section{LITERATURE OVERVIEW}

Evidence on the effectiveness of specific macroprudential tools is slowly starting to accumulate in the economics profession; however, the evidence is mixed, preliminary, and there is still much to be done (Claessens, 2014; Akinci and OlmsteadRumsey, 2018). As of yet, there is no consensus regarding which, if any, macroprudential policies are effective (Akinci and Olmstead-Rumsey, 2018). One reason for the evidence being inconclusive is that most of the empirical studies are based on aggregate data at country or bank level. Granular credit registry data to study the impact of macroprudential policies has so far been used in very few cases: Dassatti Camors et al. (2019) investigate the impact of changes in reserve requirements in Uruguay; Jiménez et al. (2017) examine dynamic provisioning in Spain; and Gambacorta and Murcia (2020) use confidential bank-loan data to shed light on the effectiveness of macroprudential policy tools and their interaction with monetary policy. 
Another reason for the mixed results is that samples used for empirical studies usually include many heterogeneous countries with different levels of development and financial integration to ensure enough observations, and this can dilute the results (Poghosyan, 2020). Moreover, many studies examine the impact of macroprudential policies only one period ahead, whereas in reality it usually takes more time for the impact of policies to become apparent. Indeed, medium- and long-term effects may be significantly different from short-term effects (Poghosyan, 2020). Furthermore, most studies do not differentiate between the impact of measures that are just recommendations; those that are legally binding; those that come with sanctions; and those that come without sanctions (ibid, 2020). Additionally, many studies use a sum of tightening and loosening macroprudential policy measures implemented in a certain time period; however, this does not capture the discretionary changes in the policy stance, i.e., which macroprudential policy instrument is concerned and how much it has changed from one period to another (Poghosyan, 2020). In our paper we use aggregate country-level banking sector balance sheet data (as opposed to granular credit registry data) in line with the majority of the existing body of research on the effects of macroprudential policy.

Most of the literature is predominantly concerned with the impact of macroprudential policy instruments on bank lending as an intermediate target instead of on bank risk, the containment of which is the ultimate macroprudential policy objective (Altunbas, Binici and Gambacorta, 2017). Recent empirical results indicate that debt-to-income caps and loan-to-value caps are more effective than capital requirements for limiting credit growth (Claessens, Ghosh and Mihet, 2013). For instance, in Switzerland the application of a countercyclical capital buffer to domestic residential mortgages had a negligible effect on loan granting (Basten and Koch, 2015). The key objective of the Basel III macroprudential tools is to bolster the resilience of the banking system (Altunbas, Binici and Gambacorta, 2017). Smoothing the credit cycle and restraining the boom is a welcome side effect which may be more or less pronounced (Drehmann and Gambacorta, 2012).

Although it is still fragmented, evidence of how effective macroprudential policy is on dampening the procyclicality of banking activity is accumulating (Galati and Moessner, 2014; Claessens, Ghosh and Mihet, 2013). Macroprudential policy instruments seem to be effective in mitigating the sensitivity of leverage and credit to the business cycle - i.e., the procyclicality of leverage and credit growth (Lim et al., 2011). Macroprudential tools also appear to be effective in restraining asset growth, leverage, and credit growth (Vandenbussche, Vogel and Detragiache, 2015; Alper et al., 2014; Cerutti, Claessens and Laeven, 2017; Claessens, Ghosh and Mihet, 2013). In spite of these positive indications that the research on macroprudential policies is proceeding in the right direction, evidence on the effectiveness of macroprudential policy measures is still in its infancy (Olszak, Roszkowska and Kowalska, 2018). Table A1 in the appendix provides an overview of some of the existing empirical literature.

The findings of the study by Davis, Liadze and Piggott (2019) suggest that, overall, the loan-to-value tool has a lower effect than capital adequacy on the probability of 
a banking crisis occurring and leads to lower net benefits. The introduction of macroprudential policy measures before the onset of a crisis leads to an improvement in key macroeconomic measures and might therefore prevent a crisis from materializing. In a similar vein, Carreras, Davis and Piggott (2018) find that macroprudential policy instruments have a positive impact on stalling household credit growth and house prices in both short- and long-run. Tools such as limits on debtto-income ratios are more effective for house prices, whilst tools such as limits on interbank exposures are more effective for household credit growth.

The results of the study by Olszak, Roszkowska and Kowalska (2019) demonstrate that, of the investigated macroprudential instruments, only borrower-based measures such as LTV and DTI caps seem to act countercyclically by weakening the positive impact of capital ratio on bank lending, in particular in crisis periods. In a comparable manner, Ma (2020) shows that macroprudential policy substantially strengthens financial stability (it reduces the frequency and probability of crises) at the cost of a small negative effect on average growth and welfare. In two extensions of the model (one with a growth subsidy and another one with a direct growth externality) the optimal macroprudential policy has a more pronounced effect on welfare and growth. Although macroprudential policy curbs average growth slightly, it is still desirable to use it, since it enhances financial stability and smooths consumption.

In the same vein, Akinci and Olmstead-Rumsey (2018) find that macroprudential tightening dampens bank credit growth, housing credit growth, and house price appreciation. Macroprudential policies targeting the housing sector appear to be more effective at constraining housing credit growth and house price appreciation, in particular in economies where bank finance is of greater importance. Counterfactual simulations indicate that, if the countries had not used any macroprudential policy measures in the period 2011-2013, the bank credit growth, housing credit growth and house price appreciation would have been substantially higher. Similarly, Meuleman and Vander Vennet (2020) demonstrate that the macroprudential policy instruments reduce individual bank risks, as well as bank systemic risk, as assessed by stock market investors. The latter is an important finding because reducing systemic risk is the key goal of macroprudential policies. Borrower-oriented tools and exposure limits are found to reduce the individual bank risk component. Liquidity measures are found to reduce the systemic linkage of banks in addition to reducing individual bank risk. Credit growth measures and exposure limits seem to lead to an increase in systemic risk component for some banks - possibly because some banks, when trying to observe the rules, take up riskier activities or similar exposures, thus exacerbating interconnectedness of the banks in the system. Macroprudential policies seem to be the most effective for distressed banks, that is banks with a high ratio of nonperforming loans. The results of the study give some indications for the optimal design of macroprudential measures.

In a comparable manner, Altunbas, Binici and Gambacorta (2017) demonstrate that macroprudential policy tools have a substantial effect on bank risk. Banks 
with different characteristics do not respond uniformly to changes in macroprudential policy tools. Small, weakly capitalized banks, and banks having a high share of wholesale funding respond more strongly to changes in macroprudential policy tools. Macroprudential policies are more efficient when employed during a downturn than during a boom. In a similar fashion, Cizel et al. (2019) investigate whether the implementation of macroprudential policy leads to a substitution of bank credit with non-bank credit. By using two global data sets on macroprudential measures and different research methodologies, the authors corroborate the presence of such substitution. Substitution with non-bank credit seems to be more conspicuous when policy measures are binding and are applied in economies with well-developed non-bank credit markets. The corollary of this is that the policies' effect on total credit is weakened, since the mentioned substitution effect to some extent counterbalances the fall in bank credit.

Similarly, Dumičić (2018) demonstrates that in the Central and Eastern European countries (CEE) macroprudential policies were more effective in weakening the flow of credit to households than the flow of credit to the non-financial corporate sector prior to the onset of the global financial crisis in 2007 . This is predominantly because the non-financial corporate sector had access not only to domestic bank credit, but also to non-bank and cross-border credit. The conclusion of the paper is that some international cooperation among policymakers is warranted so as to align macroprudential policies and prevent "regulatory arbitrage" - the circumvention of stricter regulation in one jurisdiction and the exploitation of laxer laws in another jurisdiction.

While most papers investigating the impact of macroprudential policy instruments on financial stability rely on the usage of the loan-to-value (LTV) ratio and/or countercyclical capital buffer (CCyB) as explanatory variables, our paper is unique in that it employs a wider variety of macroprudential policy instruments. In particular, we use the following explanatory variables: common equity tier 1 ratio; loans to deposits ratio; non-deposit funding as percentage of total funding; leverage ratio; interconnectedness ratio; and coverage ratio for non-performing exposures. While most of the papers on the topic of macroprudential policy investigate the impact of changes in macroprudential policy instruments on only one or two dependent variables, we employ three different dependent variables: credit growth rate; house price growth rate; and the amplitude of the deviation of the actual economic growth rate from its long-run trend. This allows us to thoroughly examine the impact of changes in selected macroprudential policy instruments on financial stability and on cyclical fluctuations of the economy. As such, our paper brings an added value to the existing body of literature. 


\subsection{DATA SPECIFICATION}

We investigate the impact of six banking sector aggregate balance sheet variables influenced by macroprudential policy instruments (common equity tier 1 ratio (CET); loan-to-deposit ratio (LDR); non-deposit funding as percentage of total funding (NDF); leverage ratio (LR); interconnectedness ratio (INR); and coverage ratio $(\mathrm{CR})$ ) on financial stability (as measured by credit growth rate (CGR) and house price growth rate (HPGR)) and on cyclical fluctuations of the economy (as measured by the amplitude of the deviation of the actual economic growth rate from its long-run trend (DEG)) by using the panel regression method. The purpose of our study is to establish whether macroprudential policy instruments do indeed enhance financial stability and dampen cyclical fluctuations of the economy.

All the data used in our econometric analysis were extracted from publicly accessible databases: the ECB's SDW - Statistical Data Warehouse of the European Central Bank (SDW, 2020) and Eurostat (Eurostat, 2020). We are using aggregate balance sheet data for the whole financial system of a particular economy. The period considered is 2015 Q1 (inclusive) to 2018 Q4 (inclusive). The countries included in our analysis are Belgium, Cyprus, Germany, Spain, Ireland and the Netherlands. These economies were chosen to ensure a balanced representation of smaller (Belgium, Cyprus, Ireland) and larger (Germany, Spain, Netherlands) European economies, as well as of southern (Spain, Cyprus) and northern European economies (Netherlands, Germany). Moreover, at the time of writing this paper (in late 2020 and early 2021) to the best of our knowledge there was no paper that investigated the impact of macroprudential policy measures on financial stability in precisely this set of economies by using panel econometrics. As such, our paper imparts an added value to the existing body of literature. In the selected time period (2015 Q1-2018 Q4) these countries used several macroprudential policy instruments at varying intensities, as demonstrated in the ECB's "Overview of macroprudential measures", "Overview of national capital-based measures" and "CCyB Data" (ECB, 2021). More information about the macroprudential policy measures applied in individual EU economies is available on the websites of macroprudential authorities and central banks of the respective countries. The following explanatory variables are employed in our paper (all retrieved from the ECB's SDW database):

$-C E T=$ common equity tier 1 ratio, measured as the amount of CET 1 capital divided by risk-weighted assets;

- LDR = loans to deposits ratio, measured as total loans, divided by total deposits; - NDF = non-deposit funding as percentage of total funding, measured as non-deposit funding, divided by total funding;

$-L R=$ leverage ratio, measured as total assets divided by total equity;

- INR = interconnectedness ratio, measured as interbank loans divided by total bank assets;

- $C R=$ coverage ratio for non-performing exposures, measured as loan-loss provisions divided by non-performing exposures ${ }^{1}$.

\footnotetext{
${ }^{1}$ Given the time span (2015-2018), the ratio captures a change in (i) the definition of NPLs (due to how EBA pushed for a uniform and conservative definition), and (ii) the way provisions were calculated - until end2017, IAS 39 with the incurred loss concept was valid while from early 2018, banks need to use IFRS 9 with its expected credit loss model.
} 
These variables are not macroprudential policy instruments per se, but rather selected ratios based on banking sector aggregate balance sheets and structural characteristics of the banking sector. The macroprudential policy implemented in the chosen countries impacts those ratios through the behaviour of banks captured by the balance sheet structure (e.g., the need to build up capital buffers such as the systemic risk buffer or countercyclical capital buffer would in general lead to increases in the CET1 ratio). These ratios can change also due to other factors (for example, CET1 ratio can go up due to banks having increased retained earnings in anticipation of expansion of balance sheets or having changed the risk profile by increasing the holdings of low-risk assets such as sovereign bonds and/or by reducing the holdings of assets to which high risk weights are assigned). Moreover, some variables, such as the CET1 ratio, can be influenced by microprudential authorities through bank-specific capital requirements (Pillar 2 requirement) and supervisory expectations communicated to the banks (Pillar 2 guidance, soft tools). Furthermore, the bank management decides on how much capital it intends to hold in excess of regulatory requirements. As such, the explanatory variables employed in our empirical analysis are proxies of macroprudential policies and can be influenced also by other policies (notably microprudential policy) and banks' own decision-making, risk aversion, profitability, and distribution policies.

The response variable in our first econometric model $\left(\mathrm{M}_{1}\right)$ which tests the first hypothesis $\left(\mathrm{H}_{1}\right.$ : "Selected banking sector aggregate balance sheet variables influenced by macroprudential policy instruments enhance financial stability, as measured by credit growth.") is:

\section{$C G R=$ credit growth rate, measured by domestic credit-to-GDP gap}

The response variable in our second econometric model $\left(\mathrm{M}_{2}\right)$ which tests the second hypothesis $\left(\mathrm{H}_{2}\right.$ : "Selected banking sector aggregate balance sheet variables influenced by macroprudential policy instruments enhance financial stability, as measured by house price growth.”) is:

\section{$H P G R=$ house price growth rate}

The response variable in our third econometric model $\left(\mathrm{M}_{3}\right)$ which tests the third hypothesis $\left(\mathrm{H}_{3}\right.$ : "Selected banking sector aggregate balance sheet variables influenced by macroprudential policy instruments reduce cyclical fluctuations of the economy, as measured by the amplitude of the deviations of the actual economic growth rate from its long-run trend, thereby contributing to financial stability.") is:

\section{$D E G=$ deviation of the real GDP growth rate from the long-run trend rate of growth}

CGR data were retrieved from the Statistical Data Warehouse of the ECB, whereas HPGR and GDP data were retrieved from Eurostat. The descriptive statistics of the explanatory and response variables are set out in table 1. 
We test three different hypotheses and use three different response variables because financial stability can be measured in different ways. Hence, the inclusion of more than one response variable can lead to more reliable results.

\section{TABLE 1}

Descriptive statistics of explanatory and response variables

\begin{tabular}{|c|c|c|c|c|c|c|c|c|c|}
\hline & d(CGR) & d(HPGR) & d(DEG) & d(CET) & d(LDR) & $d(L R)$ & d(NDF) & $\mathrm{d}(\mathrm{CR})$ & d(INR) \\
\hline Mean & -1.97 & 0.04 & 0.59 & 0.08 & 1.16 & -0.12 & -0.02 & 0.17 & -0.17 \\
\hline Median & -1.22 & -0.10 & 0.24 & 0.12 & 0.90 & -0.07 & -0.02 & -0.11 & -0.15 \\
\hline Maximum & 80.41 & 7.10 & 18.11 & 2.03 & 13.99 & 1.07 & 1.32 & 17.96 & 3.44 \\
\hline Minimum & -34.33 & -4.90 & -4.79 & -2.16 & -6.65 & -3.79 & -1.38 & -10.47 & -2.69 \\
\hline $\begin{array}{l}\text { Standard } \\
\text { deviation }\end{array}$ & 10.80 & 2.23 & 2.37 & 0.54 & 3.46 & 0.61 & 0.44 & 2.79 & 0.77 \\
\hline Skewness & 4.16 & 0.45 & 4.88 & -0.10 & 0.99 & -2.15 & 0.36 & 2.88 & 0.77 \\
\hline Kurtosis & 37.63 & 3.72 & 35.66 & 6.91 & 5.66 & 14.82 & 4.98 & 23.08 & 8.74 \\
\hline $\begin{array}{l}\text { Jarque- } \\
\text { Bera }\end{array}$ & $5,074.44$ & 5.38 & $4,648.03$ & 61.22 & 43.92 & 632.61 & 17.68 & $1,746.59$ & 141.32 \\
\hline$\overline{\text { Probability }}$ & 0.00 & 0.07 & 0.00 & 0.00 & 0.00 & 0.00 & 0.00 & 0.00 & 0.00 \\
\hline Sum & -189.22 & 3.60 & 56.73 & 8.08 & 111.21 & -11.90 & -2.19 & 16.69 & -16.60 \\
\hline $\begin{array}{l}\text { Sum sq. } \\
\text { dev. }\end{array}$ & $11,089.82$ & 470.89 & 531.76 & 28.07 & $1,136.47$ & 35.75 & 18.11 & 737.41 & 56.32 \\
\hline Obser. & 96 & 96 & 96 & 96 & 96 & 96 & 96 & 96 & 96 \\
\hline
\end{tabular}

Notes: " $d$ " denotes the first difference of a variable. For instance, $d(C G R)$ denotes the first difference of $C G R$.

Source: Authors' calculations.

\subsection{METHODOLOGY}

In order to test the three hypotheses of our paper, we employ the quantitative research method of panel econometrics. Panel regression renders it possible to study variables that have both the space dimension (in our case several countries) as well as the time dimension (in our case several quarters). Furthermore, panel regression controls for omitted variables, alleviates the problem of collinearity among explanatory variables, dismisses heterogeneous effects, and may reduce measurement errors and endogeneity bias by including the lags of the regressors. The problem of spurious regression can be circumvented by using the differences of the variables expressed as percentage changes (Festić, 2015; Hahn and Hausman, 2002; Murray, 2006). The stationarity of the times series is verified with the augmented Dickey-Fuller (ADF) test. All of our variables are stationary at first difference, however, most of them are not stationary at level (table 2). Since the linear combination of the series in a regression analysis should be at the highest order of integration, all of our time series are integrated of order one, i.e., I(1). We tried introducing the logarithmic form and lags to our models; however, these models proved to be less statistically significant and less robust than the models we present in this paper. We test both fixed effects models and the random effects models and verify their statistical significance ( $p$-values) with the redundant fixed effects test and with the Hausman test (Hausman, 1978). 
TABLE 2

Unit root test (Fisher ADF-test)

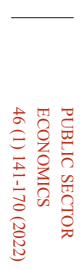

\begin{tabular}{|c|c|c|}
\hline \multirow{2}{*}{$\begin{array}{l}\text { Response and } \\
\text { explanatory variables }\end{array}$} & \multicolumn{2}{|c|}{$\begin{array}{l}\text { ADF-Fisher Chi-square statistic } \\
\text { (ADF-Fisher Chi-square probability) }\end{array}$} \\
\hline & Level (x) & First difference d(x) \\
\hline CGR & $\begin{array}{r}13.2965 \\
(0.3479)\end{array}$ & $\begin{array}{r}70.8197 \\
(0.0000)\end{array}$ \\
\hline HPGR & $\begin{array}{r}74.8063 \\
(0.0000)\end{array}$ & $\begin{array}{r}88.6962 \\
(0.0000)\end{array}$ \\
\hline DEG & $\begin{array}{r}15.3016 \\
(0.2254)\end{array}$ & $\begin{array}{r}71.0383 \\
(0.0000)\end{array}$ \\
\hline CET & $\begin{array}{r}11.9982 \\
(0.4458) \\
\end{array}$ & $\begin{array}{r}71.0925 \\
(0.0000) \\
\end{array}$ \\
\hline LDR & $\begin{array}{r}11.0842 \\
(0.5217)\end{array}$ & $\begin{array}{l}47.9746 \\
(0.0000)\end{array}$ \\
\hline LR & $\begin{array}{r}6.74768 \\
(0.8738) \\
\end{array}$ & $\begin{array}{r}71.2775 \\
(0.0000) \\
\end{array}$ \\
\hline $\mathrm{NDF}$ & $\begin{array}{l}10.2671 \\
(0.5925)\end{array}$ & $\begin{array}{r}35.9455 \\
(0.0003)\end{array}$ \\
\hline $\mathrm{CR}$ & $\begin{array}{l}5.87756 \\
(0.9221)\end{array}$ & $\begin{array}{r}54.8494 \\
(0.0000)\end{array}$ \\
\hline INR & $\begin{array}{l}4.92658 \\
(0.9604)\end{array}$ & $\begin{array}{r}88.1111 \\
(0.0000)\end{array}$ \\
\hline
\end{tabular}

Notes: p-values for the Fisher-ADF panel unit root test are computed using the asymptotic Chisquare distribution and given in brackets. The maximum number of lags was automatically selected with Schwarz Information Criterion.

Source: Authors'calculations.

The Basel III rules, which are, by and large, transposed into the EU legislative requirements, in 2013 introduced new macroprudential instruments, such as countercyclical capital buffer ( $\mathrm{CCyB})$, which limits the build-up of systemic risk in expansionary periods (Szpunar, 2017). Other buffers, which need to be met with CET1 capital, are systemic risk buffer (SRB), global systemically important institutions buffer (G-SII buffer), other systemically important institutions buffer (O-SII buffer), and capital conservation buffer (CCoB). Moreover, higher CET1 ratios can (also) be seen as a micro- and macro-prudential policy instrument, since supervisory authorities in the EU (the national supervisory authorities and the European Central Bank) in Pillar 2 supervisory review process set capital requirements for individual banks in the EU by considering their individual risk profiles and stress test results after having conducted a peer-comparison and considered micro- and macro-prudential indicators. We assume that an increase in the CET1 ratio will have a negative effect on credit growth, on house price growth, and on the amplitude of the deviations of the actual economic growth rate from its longrun trend, thereby enhancing financial stability.

The most widespread macroprudential policy tools, which existed prior to the development of Basel III, CRR and CRD IV standards and legal requirements, are 
the loan-to-value (LTV) caps and debt-to-income (DTI) caps, debt-service-toincome (DSTI) caps and loans-to-deposits (LTD) caps. LTV ratio limits the amount of the loan relative to the value of the property. The DSTI ratio limits the debt servicing cost relative to the borrower's disposable income (Szpunar, 2017). The LTD ratio (henceforth LDR) limits the amount of the loans that can be extended for each unit of currency of deposits. If the LDR is excessively high, a bank may not have sufficient liquidity in the event of loan defaults in a period of financial distress. The borrower-based tools predominantly impact the supply and demand for mortgages and other types of loans. We have decided to introduce the LDR as our borrower-based explanatory variable, since sufficiently long time series exist for this variable, and because some papers which we have reviewed use this macroprudential policy instrument to study the effect of changes in it on financial stability. We expect that an increase in the LDR will have a positive effect on credit growth, on house price growth, and on the amplitude of the deviations of the actual economic growth rate from its long-run trend, thereby undermining financial stability.

From mid-2021, the amended EU regulation sets forth a binding leverage ratio, which is a non-risk- based measure of banks' assets in relation to capital. The amount of an institution's Tier 1 capital base needs to amount to at least $3 \%$ of its non-risk-weighted assets ("exposure measure", which is a sum of on-balance sheet exposures, derivative exposures, securities financing transactions, and offbalance sheet items) ${ }^{2}$. On top of that, the global systemically important institutions (G-SIIs) will need to maintain an additional leverage ratio buffer. The purpose of the leverage ratio is to provide a back-stop to the risk-based measures and to prevent excessive leverage from building up. It does not distinguish one asset class from another (Linklaters LLP, 2019a; 2019b). We have decided to employ leverage ratio as one of the macroprudential policy instruments in which we are interested for its impact on financial stability. This is because the banks have been reporting it for some years now although it is not yet binding. Moreover, it is one of the few measures that do not depend on the risk-weighted assets, but simply on assets without having risk weights applied to them. Our conjecture is that an increase in the leverage ratio (measured as total assets divided by total equity) will have a positive impact on credit growth, on house price growth, and on the amplitude of the deviations of the actual economic growth rate from its long-run trend, thereby compromising financial stability.

It is not just adequate capitalization of banks which contributes to financial stability; another aspect is adequate measuring and managing of the level of banks' liquidity and their resilience to liquidity shocks. In response to the Great Financial Crisis of 2007, the Basel Committee on Banking Supervision (henceforth BCBS) introduced two liquidity standards - LCR (liquidity coverage ratio to control short-term liquidity

\footnotetext{
${ }^{2}$ In our analysis we actually use a more traditional definition of the leverage ratio (i.e., total assets divided by total equity), but the general idea is the same.
} 
risk) and NSFR (net stable funding ratio to monitor structural resilience). In our analysis we do not use any of the new liquidity measures due to the insufficient length of the time series. Instead, we use NDF, that is non-deposit funding expressed as a percentage of total funding. Deposits are in general the most traditional and stable source of funding. A high percentage of non-deposit funding in the total funding sources of a bank indicates that a bank is striving to expand its balance sheet at the expense of maturity mismatches, higher liquidity risk and greater dependence on market conditions. We expect that an increase in non-deposit funding expressed as a percentage of total funding will have a positive effect on credit growth, on house price growth, and on the amplitude of the deviations of the actual economic growth rate from its longrun trend, thereby endangering financial stability.

Some of the vulnerabilities and risks which led to the 2007 global financial crisis, and which could nowadays be spotted, mitigated and perhaps even altogether prevented by macroprudential policy instruments, were excessive mortgage growth, drying-up of market liquidity when risk aversion rose, concentration of risk in the financial system, intertwined vulnerabilities of financial institutions, and excessive interlinkages between financial intermediaries and across markets (Bini Smaghi, 2009a; 2009b). In addition to insufficient capital cushions and inadequate structure of funding sources, other factors which contributed to the 2007 global financial crisis were insufficient coverage ratios, as well as the imprudent loan loss provisioning and impairment practices of many financial institutions (Frait and Komárková, 2013). Coverage ratio is calculated as loan loss provisions expressed as a percentage of non-performing exposures. In our dissertation we will be interested in the impact of changes in coverage ratio (as one of our explanatory variables) on financial stability. We have decided to use coverage ratio, since this ratio indicates how well prepared the banks are to cover losses arising from non-performing loans out of provisions set aside in advance. If the coverage ratio is equal to $100 \%$, all non-performing loans are completely covered with provisions. The higher the coverage ratio, the better. We surmise that an increase in the coverage ratio will have a negative effect on credit growth, on house price growth, and on the amplitude of the deviations of the actual economic growth rate from its long-run trend, thereby enhancing financial stability.

Last but not least macroprudential policy instrument which we have decided to include in our analysis is the bank interconnectedness ratio, calculated as the amount of interbank loans, divided by total bank assets (SDW, 2020). The higher the bank interconnectedness ratio, the more likely that a shock to bank's external assets or liabilities will have systemic repercussions (i.e., will not stay with just one bank, but will be transferred also to other banks in the system). The lower the interconnectedness ratio, i.e., the more diversified banks' portfolios, the lower the likelihood and the strength of the propagation of contagion (Roncoroni et al., 2019). We suppose that an increase in the bank interconnectedness ratio will have a positive effect on credit growth, on house price growth, and on the amplitude of the deviations of the actual economic growth rate from its long-run trend, thereby undermining financial stability. 
Empirical results, displayed in table 3, allow us to corroborate or reject each of the three hypotheses. Regarding the first hypothesis (an increase in CET has a negative effect on CGR; an increase in LDR has a positive effect on CGR; an increase in LR has a positive effect on CGR; an increase in NDF has a positive effect on CGR; an increase in CR has a negative effect on CGR; an increase in INR has a positive effect on CGR), we can only partially confirm it, given that the results of the first empirical model indicate that an increase in CET has a negative effect on CGR (thus confirming our first hypothesis); an increase in LDR has a negative effect on CGR (thus rejecting our first hypothesis); an increase in LR has a negative effect on CGR (thus rejecting our first hypothesis); an increase in NDF has a negative effect on CGR (thus rejecting our first hypothesis); an increase in CR has a negative effect on CGR (thus confirming our first hypothesis); an increase in INR has a positive effect on CGR (thus confirming our first hypothesis). Since only three regressors (out of six) have the signs predicted by Hypothesis 1, we can only partly confirm Hypothesis 1 .

Regarding the second hypothesis (an increase in CET has a negative effect on HPGR; an increase in LDR has a positive effect on HPGR; an increase in LR has a positive effect on HPGR; an increase in NDF has a positive effect on HPGR; an increase in CR has a negative effect on HPGR; an increase in INR has a positive effect on HPGR), we can only partially confirm it, given that the results of the second empirical model indicate that an increase in CET has a negative effect on HPGR (thus confirming our second hypothesis); an increase in LDR has a positive effect on HPGR (thus confirming our second hypothesis); an increase in LR has a positive effect on HPGR (thus confirming our second hypothesis); an increase in NDF has a negative effect on HPGR (thus rejecting our second hypothesis); an increase in CR has a positive effect on HPGR (thus rejecting our second hypothesis); an increase in INR has a negative effect on HPGR (thus rejecting our second hypothesis). Since only three regressors (out of six) have the signs predicted by Hypothesis 2 (in the period fixed effects model), we can only partly confirm Hypothesis 2.

Regarding the third hypothesis (an increase in CET has a negative effect on DEG; an increase in LDR has a positive effect on DEG; an increase in LR has a positive effect on DEG; an increase in NDF has a positive effect on DEG; an increase in CR has a negative effect on DEG; an increase in INR has a positive effect on DEG), we can only partially confirm it, given that the results of the third empirical model indicate that an increase in CET has a negative effect on DEG (thus confirming our third hypothesis); an increase in LDR has a negative effect on DEG (thus rejecting our third hypothesis); an increase in LR has a negative effect on DEG (thus rejecting our third hypothesis); an increase in NDF has a negative effect on DEG (thus rejecting our third hypothesis); an increase in CR has a negative effect on DEG (thus confirming our third hypothesis); an increase in INR has a positive effect on DEG (thus confirming our third hypothesis). Since only three regressors (out of six) have the signs predicted by Hypothesis 3 (in the 
cross-section fixed effects model and in the period random effects model), we can only partly confirm Hypothesis 3 .

Formal econometric tests help us to decide which model is more appropriate for use in a certain situation. The redundant fixed effects test is used to decide between the pooled model and the fixed effects model. If the null hypothesis is not rejected $(p>0.1)$, fixed effects are not present in the model. If the alternative hypothesis is not rejected $(p<0.1)$, fixed effects are present in the model. The Hausman test is used to distinguish between the fixed effects model and the random effects model. If the null hypothesis is not rejected ( $p>0.1)$, the random effects estimator is consistent and efficient. On the other hand, if the alternative hypothesis is not rejected $(p<0.1)$, the fixed effects estimator is at least as consistent as the random effects estimator and hence preferred (Gujarati, 2003; Allison, 2009; Hsiao, 1985; Wooldridge, 2010).

The empirical results set out in table 3 indicate that period fixed effects as well as cross-section fixed effects and period fixed effects together are present in the first model where CGR is the dependent variable, since the $F$ probability of the redundant fixed effects test is less than 0.1. In the second model where HPGR is the dependent variable, only period fixed effects are present, since the $F$ probability of the redundant fixed effects test is less than 0.05. In the third model where DEG is the dependent variable, only cross-section fixed effects are present, since the $F$ probability of the redundant fixed effects test is less than 0.1 . In all three models, the p-value of the Hausman test is above 0.1 (it ranges from 0.28 to 0.57 ), meaning that we cannot reject the null hypothesis of the Hausman test. Hence, the random effects estimator is consistent and efficient and therefore preferred over the fixed effects estimator in all three models.

The Durbin-Watson (DW) statistic tests whether there is autocorrelation in the residuals from a regression model. A value of 2 indicates that no autocorrelation is present in the sample. Values between 2 and 4 indicate the presence of negative autocorrelation, whereas values from 0 to 2 indicate the presence of positive autocorrelation. The Durbin-Watson statistic is the closest to 2 (a value which indicates there is no autocorrelation detected in the sample) in the third model where DEG is the dependent variable (DW statistics ranges from 1.77 to 2.03). In the second model where HPGR is the dependent variable, some negative autocorrelation may be present (DW statistics ranges from 2.87 to 3.03 ). In the first model where CGR is the dependent variable, some positive autocorrelation may be present (DW statistics ranges from 1.45 to 1.57 ).

The Hansen-Sargan test of overidentifying restrictions tests whether the excluded instruments are distributed independently of the error process (i.e., instruments are valid, $(\mathrm{Cov}(\mathrm{z}, \mathrm{u})=0))$. The null hypothesis $\left(\mathrm{H}_{0}\right)$ of the Hansen-Sargan test is that the instrumental variables are uncorrelated with the error term. The alternative hypothesis $\left(\mathrm{H}_{1}\right)$ is that the instrumental variables are correlated with the error 
term (Festić, Kavkler and Repina, 2011). The Kleibergen-Paap test of underidentification tests whether the excluded instruments are correlated with the endogenous regressors $(\operatorname{Cov}(\mathrm{z}, \mathrm{x}) \neq 0)$. The null hypothesis $\left(\mathrm{H}_{0}\right)$ of the Kleibergen-Paap test is that the chosen instruments are weak. The alternative hypothesis $\left(\mathrm{H}_{1}\right)$ is that the instruments are not weak (Festić, Kavkler and Repina, 2011). In our case, the Hansen-Sargan statistic of overidentifying restrictions does not reject the null hypothesis that the instrumental variables are uncorrelated with the error term (table 3). Rejection of the null hypothesis of the Kleibergen-Paap test, on the other hand, suggests that the chosen instruments are not weak.

Overall, based on the empirical results, we:

- Partly confirm Hypothesis 1: "Selected banking sector aggregate balance sheet variables influenced by macroprudential policy instruments (common equity tier 1 ratio; loan-to-deposit ratio; non-deposit funding as percentage of total funding; leverage ratio; interconnectedness ratio; and coverage ratio for non-performing exposures) enhance financial stability, as measured by credit growth."

- Partly confirm Hypothesis 2: "Selected banking sector aggregate balance sheet variables influenced by macroprudential policy instruments (common equity tier 1 ratio; loan-to-deposit ratio; non-deposit funding as percentage of total funding; leverage ratio; interconnectedness ratio; and coverage ratio for non-performing exposures) enhance financial stability, as measured by house price growth."

- Partly confirm Hypothesis 3: "Selected banking sector aggregate balance sheet variables influenced by macroprudential policy instruments (common equity tier 1 ratio; loan-to-deposit ratio; non-deposit funding as percentage of total funding; leverage ratio; interconnectedness ratio; and coverage ratio for non-performing exposures) reduce cyclical fluctuations of the economy, as measured by the amplitude of the deviations of the actual economic growth rate from its long-run trend, thereby contributing to financial stability." 

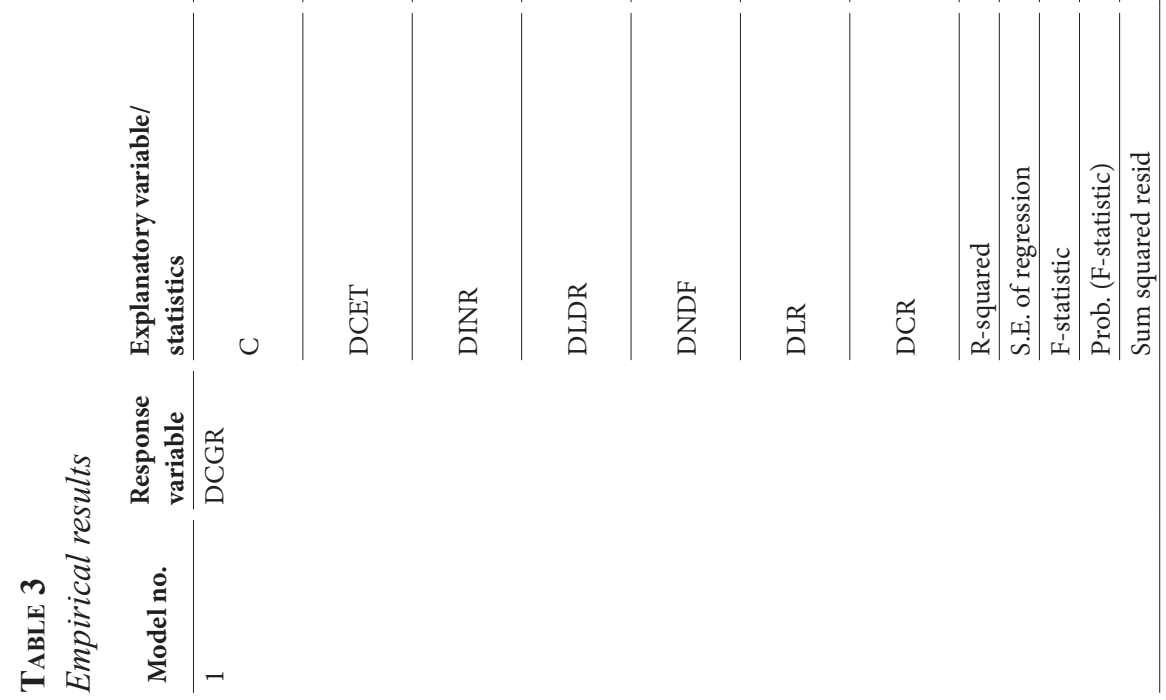

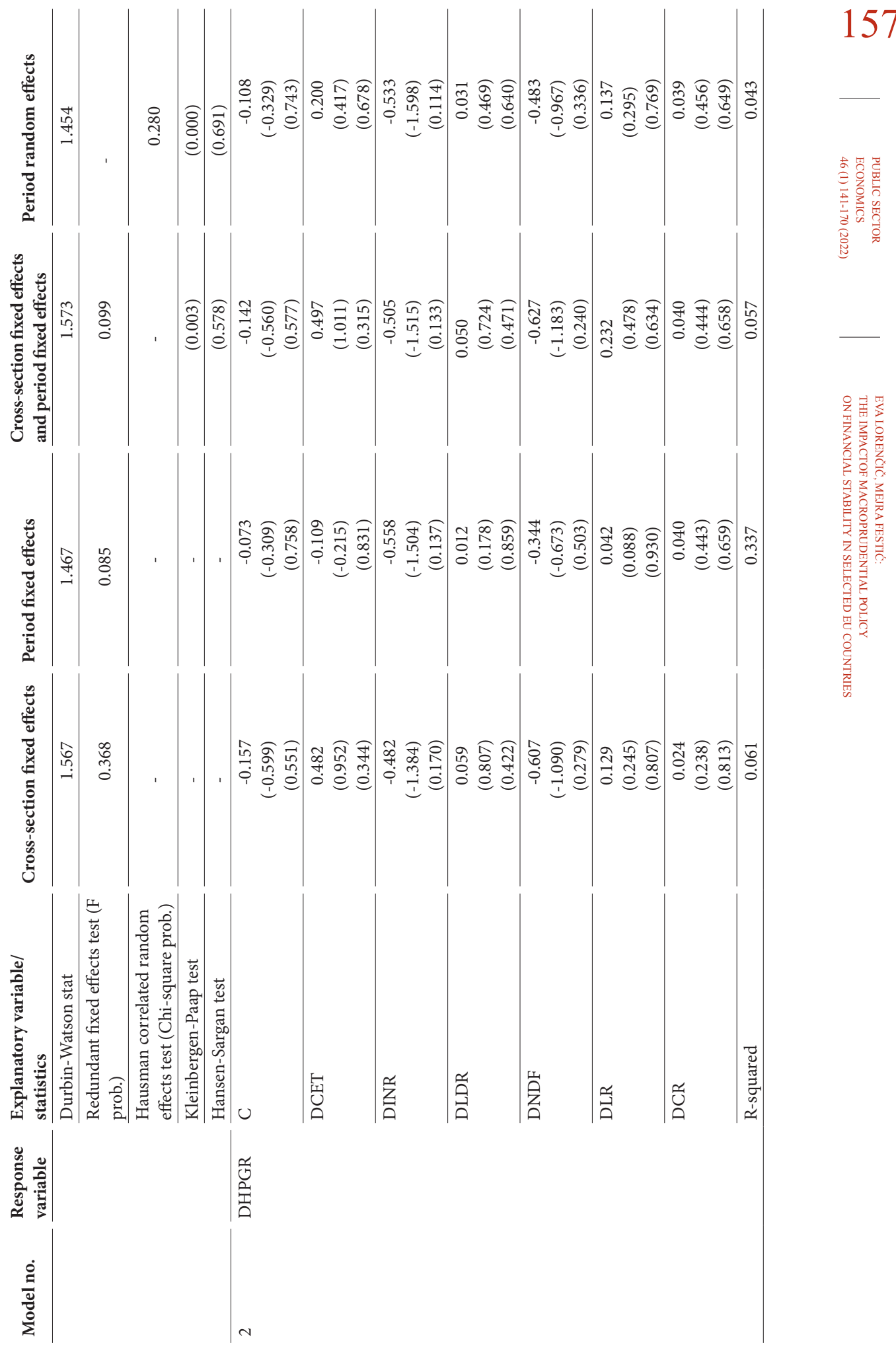


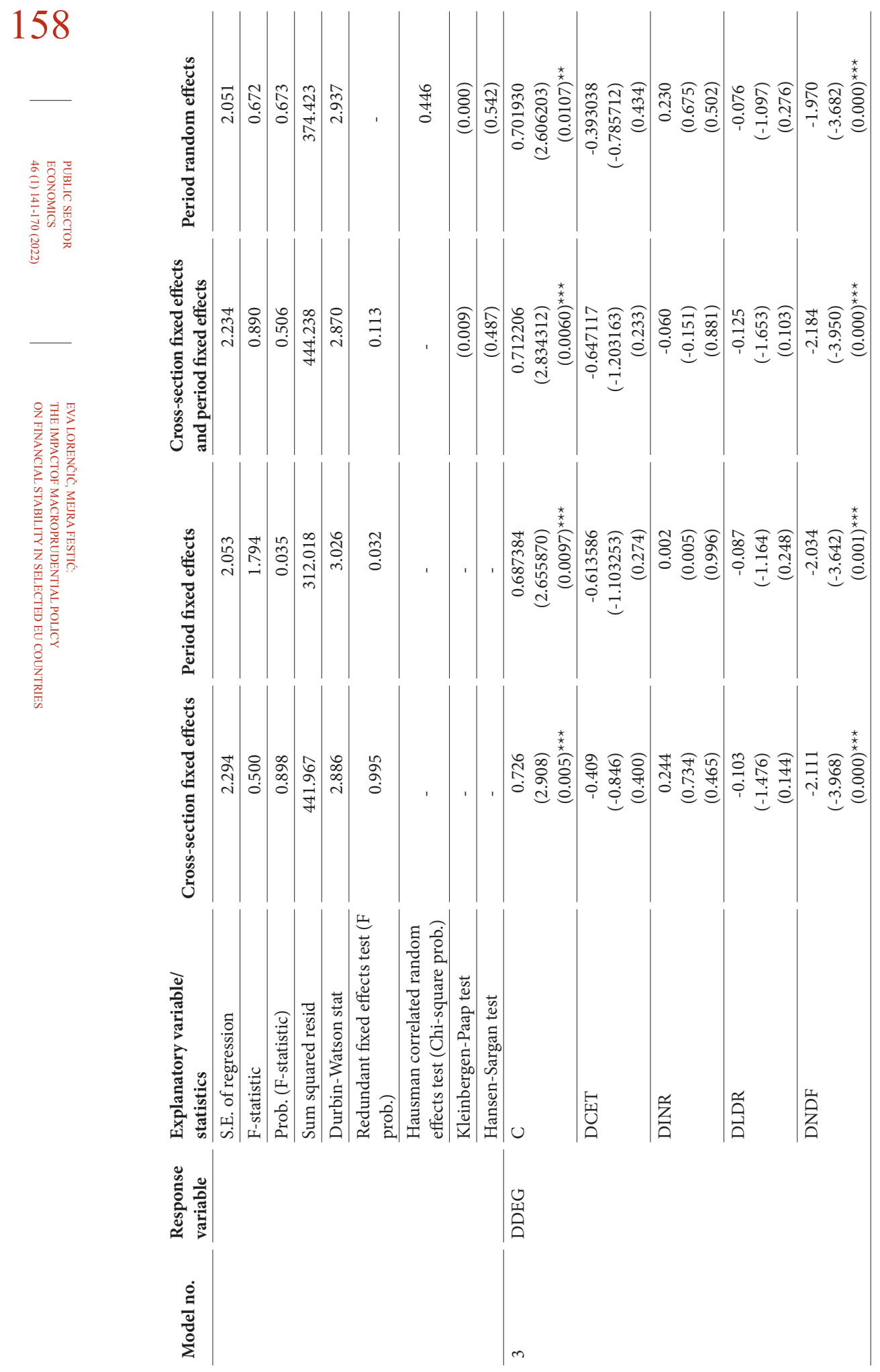



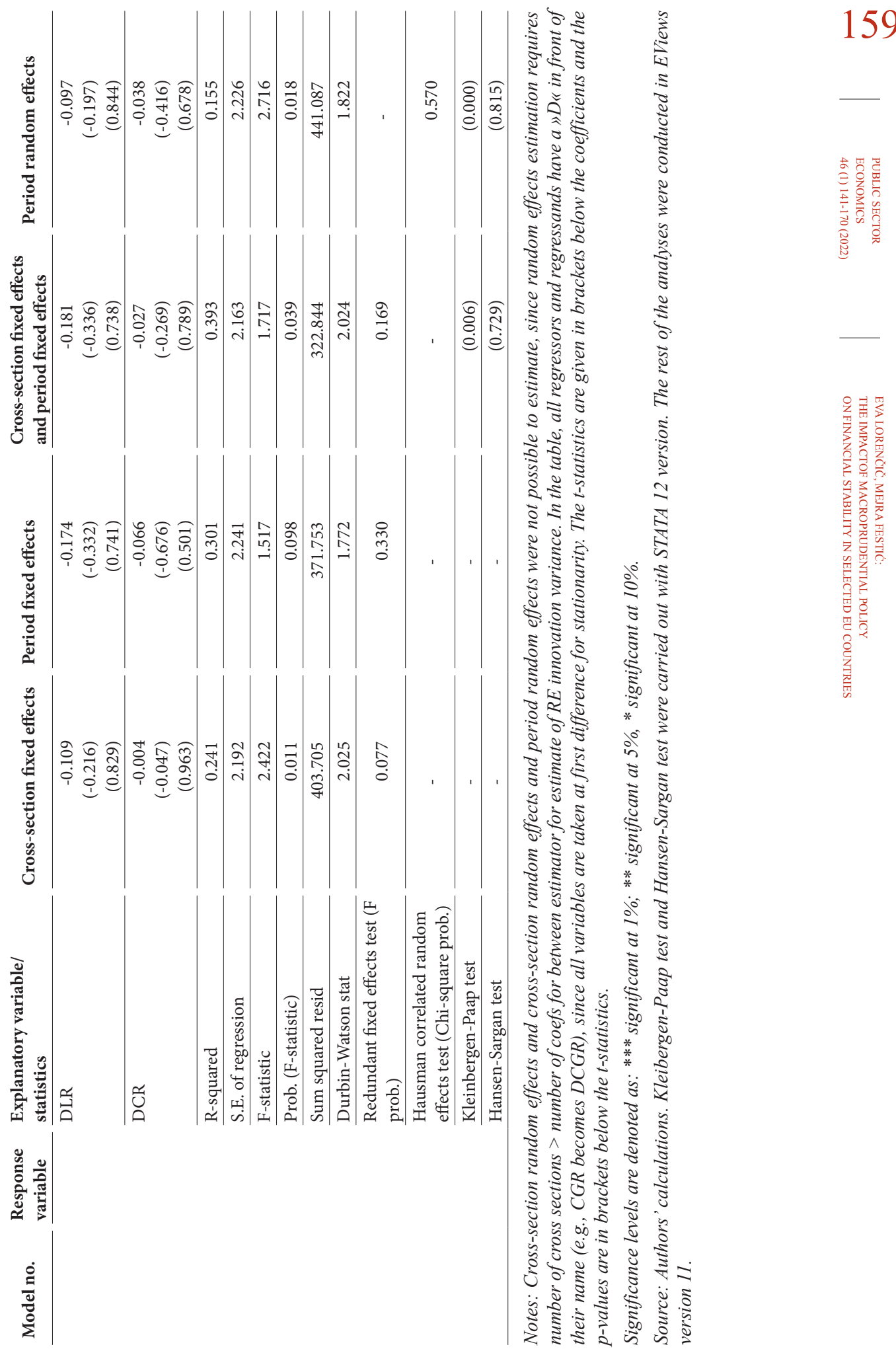
It seems that the empirical results vary to some extent in relation to the chosen empirical research method, as demonstrated in table A1 (in the appendix) with empirical research overview. Moreover, it appears that the empirical results are contingent also on the choice of individual macroprudential policy instruments; time period; and set of economies. Our empirical results indicate that selected banking sector aggregate balance sheet variables influenced by macroprudential policy instruments have a certain impact on financial stability; however, more research is needed into, for instance, why different models are more appropriate (statistically significant) for different response variables. In particular, period fixed effects; cross-section fixed and period fixed effects model; and period random effects model were suitable for the analysis of the impact of explanatory variables on CGR as the response variable; only the period fixed effects model was suitable for the analysis of the impact of explanatory variables on HPGR as the response variable; only the cross-section fixed effects model and the period random effects model were suitable for the analysis of the impact of explanatory variables on DEG as the response variable.

The period under investigation (2015 Q1-2018 Q4) was characterized by loose monetary policy in the euro area and slowly but surely increasing financial stability risks. No economic crisis or downturn occurred in the period. Our data set can shed some light on how macroprudential policy could reduce rising financial stability risks, but it cannot provide information on its effects in a crisis, where financial stability might be compromised (for example, previously built capital buffers can cushion the shocks). As already stated, in our analysis we were limited by the availability of the data and were faced with a lack of longer time series for the selected variables and countries. In future research, variables spanning the entire economic/financial cycle could be included, which would also allow us to investigate the impact of macroprudential policy instruments in a crisis period.

The weaknesses of our regression models are that they do not capture well the interactions between macroprudential policy instruments, financial and real economic sectors, and the macroprudential policy transmission mechanism. Furthermore, we did not isolate the effects of macroprudential policy from those of monetary policy and microprudential policy (Carreras, Davis and Piggott, 2018). Our study does not allow for a possible correlation between time series processed in the long term because the variables are included only in differences. This does not allow us to study the long-term effects of macroprudential policy instruments. Furthermore, certain macroprudential policy instruments appear to influence credit growth, house price growth, and cyclical fluctuations of the economy differently from our expectations. For instance, we would expect that an increase in the non-deposit funding (as percentage of total funding) increases credit growth, house price growth, and amplifies cyclical fluctuations of the economy, thereby undermining financial stability. However, our empirical results indicate that the opposite is the case. A plausible explanation for this could be that in economic downturns, when credit growth is lower or negative and when more people lose 
their jobs and when salary increases are hard to come by, retail depositors do not have excess liquidity to deposit with banks, hence the banks start relying more on non-deposit funding sources. In this case the causal relationship goes from the state of the economy (credit expansion or contraction) to the changes in the calibration of macroprudential instruments (in this case the maximum allowed nondeposit funding as percentage of total funding).

Indeed, methodologically, any estimation deals with the inherent endogeneity problem, since policymakers usually implement measures in response to systemic risk, credit and financial cycles, indicated by, for example, excessive credit growth or excessive house price growth (Cizel et al., 2019; Gadatsch, Mann and Schnabel, 2018). As such, macroprudential policy instruments may be influenced by the target variables, which creates reverse causality. This could lead to an estimation bias, underestimating the effectiveness of macroprudential policy measures (Kuttner and Shim, 2016). The panel GMM estimator may alleviate this problem (Lim et al., 2011; Claessens, Ghosh and Mihet, 2013; Cerutti, Claessens and Laeven, 2017). However, panel GMM estimators suffer from the weak instrument problem (Bun and Windmeijer, 2010). They also produce many econometric instruments because their numbers grow with the time dimension. The model can become overfitted and tests for the validity of instruments may become difficult to use (Roodman, 2009). Another option would be to employ instrumental variables in line with Gadatsch, Mann and Schnabel (2018). Yet another possibility would be to focus on the side effects of macroprudential policy measures and on nonbank credit in line with Cizel et al. (2019). The changes in nonbank credit will probably have a lesser impact on macroprudential policy measures that apply to the banking sector. That said, nonbank credit and bank credit can be correlated, hence the changes in nonbank credit may still influence policy decisions to some extent, implying that some endogeneity may remain. These research suggestions, however, go beyond the scope of our present research and may be tackled in the future.

\section{CONCLUSION}

Since the Great Financial Crisis of 2007, macroprudential policy instruments have gained in recognition as a crucial tool for enhancing financial stability. Monetary policy, fiscal policy, and microprudential policy operate with a different toolkit and focus on achieving goals other than stability of the financial system as a whole. In light of this, a fourth policy - namely macroprudential policy - is required to mitigate and prevent shocks that could destabilise the financial system as a whole and compromise financial stability. Since macroprudential policy came to the forefront of the economic profession only recently, the evidence on the effectiveness of specific macroprudential tools is still scarce. Our paper is a contribution to this field.

We tested three hypotheses: $\mathrm{H}_{1}$ : Selected banking sector aggregate balance sheet variables influenced by macroprudential policy instruments (common equity tier 1 ratio; loan-to-deposit ratio; non-deposit funding as percentage of total funding; 
leverage ratio; interconnectedness ratio; and coverage ratio for non-performing exposures) enhance financial stability, as measured by credit growth. $\mathrm{H}_{2}$ : Selected banking sector aggregate balance sheet variables influenced by macroprudential policy instruments (common equity tier 1 ratio; loan-to-deposit ratio; non-deposit funding as percentage of total funding; leverage ratio; interconnectedness ratio; and coverage ratio for non-performing exposures) enhance financial stability, as measured by house price growth. $\mathrm{H}_{3}$ : Selected banking sector aggregate balance sheet variables influenced by macroprudential policy instruments (common equity tier 1 ratio; loan-to-deposit ratio; non-deposit funding as percentage of total funding; leverage ratio; interconnectedness ratio; and coverage ratio for non-performing exposures) reduce cyclical fluctuations of the economy, as measured by the amplitude of the deviations of the actual economic growth rate from its long-run trend, thereby contributing to financial stability.

Our empirical results suggest that, of the investigated banking sector aggregate balance sheet variables influenced by macroprudential policy instruments, common equity tier one ratio, coverage ratio, and interconnectedness ratio exhibit the predicted impact on credit growth rate and on the deviation of the actual economic growth rate from its long-run trend. Furthermore, common equity tier one ratio, loan-to-deposit ratio, and leverage ratio exhibit the predicted impact on house price growth rate. The non-deposit funding ratio does not exhibit the expected impact on any of the response variables. Hence, we can only partly confirm hypotheses 1,2 and 3 .

Taking into account the existing empirical research, combined with our findings as presented in this paper, a case can be made for the use of carefully crafted macroprudential policy instruments that target selected financial and macroeconomic variables with the ultimate goal of attaining the stability of the financial system as a whole.

Avenues for future research are the inclusion of additional macroprudential policy instruments in our models; the use of different empirical research methods; as well as a consideration of different time periods and different sets of economies.

\section{Disclosure statement}

All authors state that they do not have any financial or other substantive conflict of interest. 
1. Akinci, O. and Olmstead-Rumsey, J., 2018. How effective are macroprudential policies? An empirical investigation. Journal of Financial Intermediation, 33(C), pp. 33-57. https://doi.org/10.1016/j.jfi.2017.04.001

2. Allison, P., 2009. Fixed Effects Regression Models. Thousand Oaks, CA: Sage Publications. https://dx.doi.org/10.4135/9781412993869

3. Alper, K. [et al.], 2014. Reserve Requirements, Liquidity Risk, and Credit Growth. Working Paper No. 14/24. Ankara: Central Bank of the Republic of Turkey.

4. Altunbas, Y., Binici, M. and Gambacorta, L., 2017. Macroprudential policy and bank risk. Bank for International Settlements. BIS Working Papers, No. 646.

5. Altunbas, Y., Gambacorta, L. and Marques-Ibanez, D., 2014. Does monetary policy affect bank risk? International Journal of Central Banking, 10(1), pp. 95-135.

6. Basten, C. and Koch, C., 2015. Higher bank capital requirements and mortgage pricing: Evidence from the countercyclical capital buffer (CCB). BIS Working Papers, No. 511.

7. Bini Smaghi, L., 2009a. Going Forward: Regulation and Supervision after the Financial Turmoil. Speech at Bocconi University, Milan (Italy), 19 June 2009.

8. Bini Smaghi, L., 2009b. Macro-prudential supervision. Speech at the CEPR/ ESI 13 th Annual Conference on "Financial Supervision in an Uncertain World”, European Banking Center at Venice International University, Venice, 25-26 September 2009.

9. Borio, C., 2011. Implementing the macroprudential approach to financial regulation and supervision. In: C. J. Green, E. Pentecost and T. Weyman-Jones, eds. The Financial Crisis and the Regulation of Finance. Edward Elgar: Cheltenham, UK.

10. Bun, M. G. and Windmeijer, F., 2010. The weak instrument problem of the system GMM estimator in dynamic panel data models. The Econometrics Journal, 13(1), pp. 95-126. https://doi.org/10.1111/j.1368-423X.2009.00299.x

11. Carreras, O., Davis, P. E. and Piggott, R., 2018. Assessing macroprudential tools in OECD countries within a cointegration framework. Journal of Financial Stability, 37(C), pp. 112-130. https://doi.org/10.1016/j.jfs.2018.04.004

12. Cerutti, E., Claessens, S. and Laeven, L., 2017. The use and effectiveness of macroprudential policies: New evidence. Journal of Financial Stability, 28(C), pp. 203-224. https://doi.org/10.1016/j.jfs.2015.10.004

13. Cizel, J. [et al.], 2019. Effective Macroprudential Policy: Cross-Sector Substitution from Price and Quantity Measures. Journal of Money, Credit and Banking, 51(5), pp. 1209-1235. https://doi.org/10.1111/jmcb.12630

14. Claessens, S., 2014. An Overview of Macroprudential Policy Tools. IMF Working Paper, WP/14/214.

15. Claessens, S., Ghosh, S. R. and Mihet, R., 2013. Macro-Prudential Policies to Mitigate Financial System Vulnerabilities. Journal of International Money and Finance, 39(C), pp. 153-185. https://doi.org/10.1016/j.jimonfin.2013.06.023 
16. Crockett, A. D., 2000. Marrying the micro- and macroprudential dimensions of financial stability. BIS Speeches, 21 September 2000.

17. Dassatti Camors, C. [et al.], 2019. Macroprudential and Monetary Policy: LoanLevel Evidence from Reserve Requirements. Economics Working Papers, No. 1650 .

18. Davis, E. P., Liadze, I. and Piggott, R., 2019. Assessing the macroeconomic impact of alternative macroprudential policies. Economic Modelling, 80(C), pp. 407-428. https://doi.org/10.1016/j.econmod.2018.11.025

19. Drehmann, M. and Gambacorta, L., 2012. The effects of countercyclical capital buffers on bank lending. Applied Economics Letters, 19(7), pp. 603-608. https://doi.org/10.1080/13504851.2011.591720

20. Dumičić, M., 2018. Effectiveness of macroprudential policies in Central and Eastern European countries. Public Sector Economics, 42(1), pp. 1-19. https:// doi.org/10.3326/pse.42.1.1

21. ECB, 2020. Financial stability and macroprudential policy.

22. ECB, 2021. Countercyclical capital buffer.

23. Eurostat, 2020. Statistical Office of the European Union.

24. Festić, M., 2015. The Stability of the Credit Supply in the Globalized Banking Sector Environment: The Case of the EU New Member States-10. Prague Economic Papers, 24(4), pp. 386-398. https://doi.org/10.18267/j.pep.543

25. Festić, M., Kavkler, A. and Repina, S., 2011. The macroeconomic sources of systemic risk in the banking sectors of five new EU member states. Journal of Banking \& Finance, 35(2), pp. 310-322. https://doi.org/10.1016/j.jbankfin. 2010.08.007

26. Frait, J. and Komárková, Z., 2013. Loan Loss Provisioning in Selected European Banking Sectors: Do Banks Really Behave in a Procyclical Way? Czech Journal of Economics and Finance, 63(4), pp. 308-326.

27. Gadatsch, N., Mann, L. and Schnabel, I., 2018. A new IV approach for estimating the efficacy of macroprudential measures. Economic Letters, 168(C), pp. 107-109. https://doi.org/10.1016/j.econlet.2018.04.015

28. Galati, G. and Moessner, R., 2011. Macroprudential Policy - A Literature Review. Journal of Economic Surveys, 27(5), pp. 846-878. https://doi.org/10. 1111/j.1467-6419.2012.00729.x

29. Galati, G. and Moessner, R., 2014. What Do We Know About the Effects of Macroprudential Policy? DNB Working Paper, No. 440.

30. Gambacorta, L. and Murcia, A., 2020. The impact of macroprudential policies in Latin America: An empirical analysis using credit registry data. Journal of Financial Intermediation, 42(C), 100828. https://doi.org/10.1016/j.jfi.2019. 04.004

31. Gujarati, D., 2003. Basic Econometrics (fourth edition). McGraw-Hill: United States.

32. Hahn, J. and Hausman, J., 2002. A New Specification Test for the Validity Instrumental Variables. Econometrica, 70(1), pp. 163-189. https://doi. org/10.1111/1468-0262.00272 
33. Hausman, J. A., 1978. Specification Test in Econometrics. Econometrica, 46(6), pp. 1251-1272. https://doi.org/10.2307/1913827

34. Hsiao, C., 1985. Benefits and Limitations of Panel Data. Econometric Reviews, 4(1), pp. 121-174. https://doi.org/10.1080/07474938508800078

35. Jiménez, G. [et al.], 2017. Macroprudential policy, countercyclical bank capital buffers and credit supply: Evidence from the Spanish dynamic provisioning experiments. Journal of Political Economy, 125(6), pp. 2126-2177. https:// doi.org/10.1086/694289

36. Kuttner, K. N. and Shim, I., 2016. Can non-interest rate policies stabilise housing markets? Evidence from a panel of 57 economies. Journal of Financial Stability, 26(C), pp. 31-44. https://doi.org/10.1016/j.jfs.2016.07.014

37. Lim, C. H. [et al.], 2011. Macroprudential policy: What Instruments and How to Use Them? Lessons from Country Experiences. IMF Working Paper, No. $11 / 238$.

38. Linklaters LLP, 2019a. CRR2 and CRDV - The New EU Prudential Regulatory Landscape.

39. Linklaters LLP, 2019b. CRR2 and CRDV-The New EU Prudential Regulatory Landscape.

40. Ma, C., 2020. Financial stability, growth and macroprudential policy. Journal of International Economics, 122(C), 103259. https://doi.org/10.1016/j.jinteco.2019.103259

41. Meuleman, E. and Vander Vennet, R., 2020. Macroprudential policy and bank systemic risk. Journal of Financial Stability, 47(C), 100724. https://doi. org/10.1016/j.jfs.2020.100724

42. Murray, M. P., 2006. Avoiding Invalid Instruments and Coping with Weak Instruments. Journal of Economic Perspectives, 20(4), pp. 111-132. https:// doi.org/10.1257/jep.20.4.111

43. Olszak, M., Roszkowska, S. and Kowalska, I., 2018. Macroprudential policy instruments and procyclicality of loan-loss provisions - Cross-country evidence. Journal of International Financial Markets, Institutions \& Money, 54(C), pp. 228-257. https://doi.org/10.1016/j.intfin.2018.01.001

44. Olszak, M., Roszkowska, S. and Kowalska, I., 2019. Do macroprudential policy instruments reduce the procyclical impact of capital ratio on bank lending? Cross-country evidence. Baltic Journal of Economics, 19(1), pp. 1-38. https://doi.org/10.1080/1406099X.2018.1547565

45. Poghosyan, T., 2020. How Effective is Macroprudential Policy? Evidence from Lending Restriction Measures in EU Countries. Journal of Housing Economics, 49(C), 101694. https://doi.org/10.1016/j.jhe.2020.101694

46. Roncoroni, A. [et al.], 2019. Interconnected banks and systemically important exposures. ECB Working Paper Series, No. 2331.

47. Roodman, D., 2009. A note on the theme of too many instruments. Oxford Bulletin of Economics and Statistics, 71(1), pp. 135-158. https://doi.org/10.11 11/j.1468-0084.2008.00542.x 
48. SDW, 2020. European Central Bank: Statistical Data Warehouse.

49. Szpunar, P., 2017. Institutional and operational aspects of macroprudential policy in central and eastern European EU member states. BIS Papers chapters. In: Bank for International Settlements. Macroprudential policy frameworks, implementation and relationships with other policies, pp. 289-303.

50. Vandenbussche, J., Vogel, U. and Detragiache, E., 2015. Macroprudential policies and housing prices: A new database and empirical evidence for Central, Eastern, and Southeastern Europe. Journal of Money, Credit and Banking, 47(1), pp. 343-377. https://doi.org/10.1111/jmcb.12206

51. Wooldridge, J. M., 2010. Econometric Analysis of Cross Section and Panel Data. Cambridge, MA: MIT Press. 


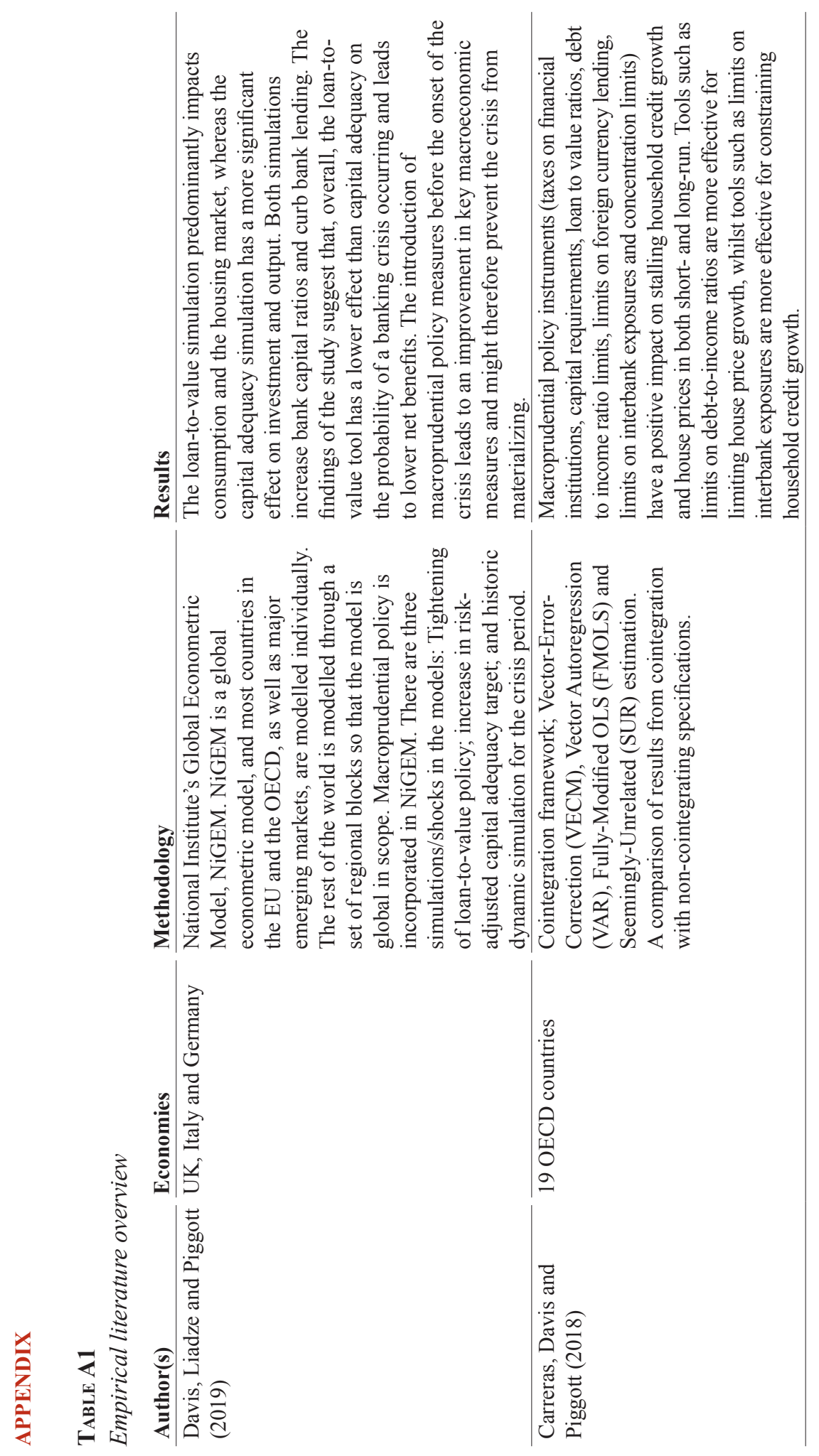

167
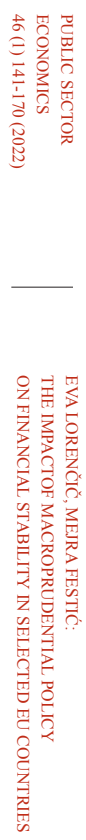
168
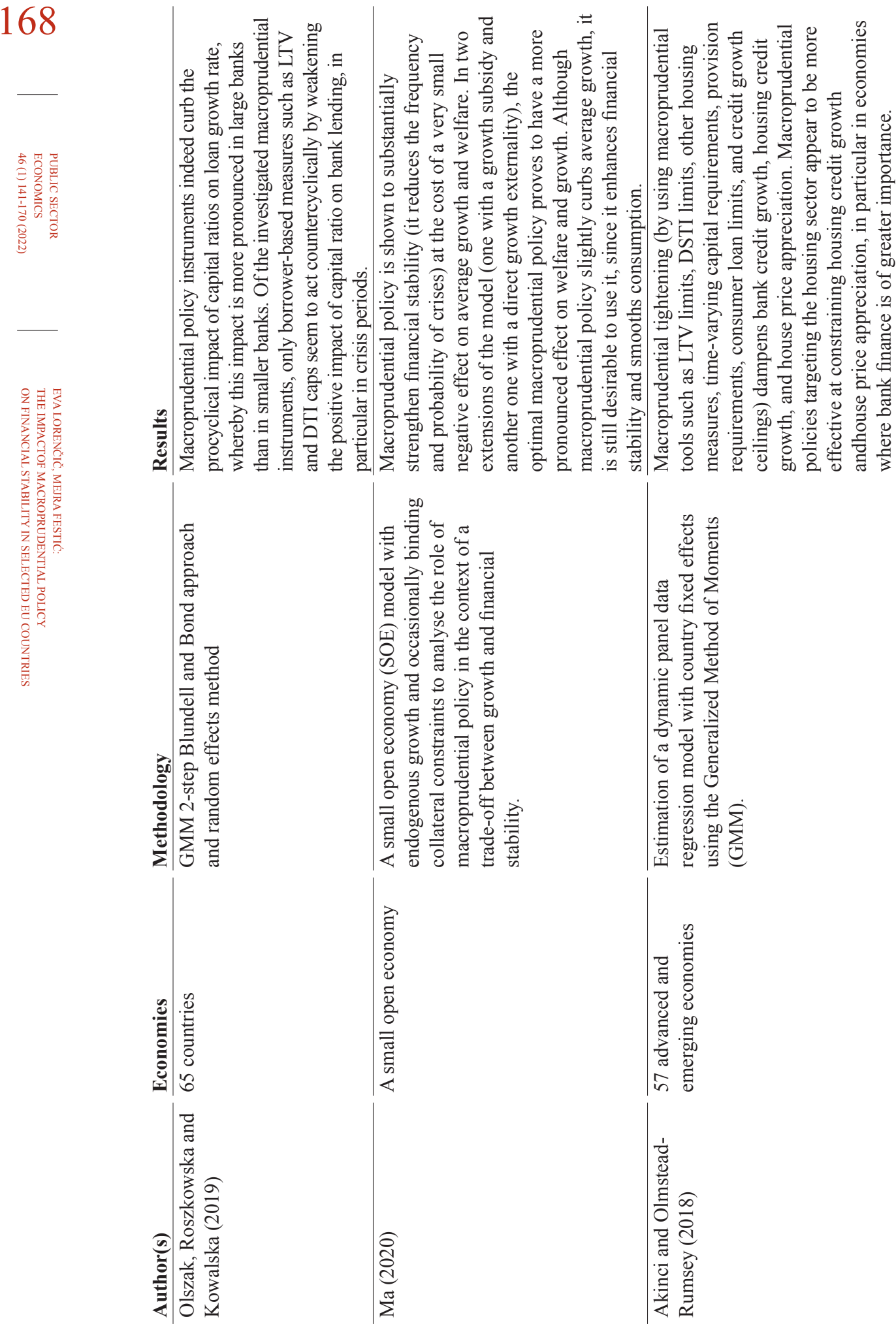


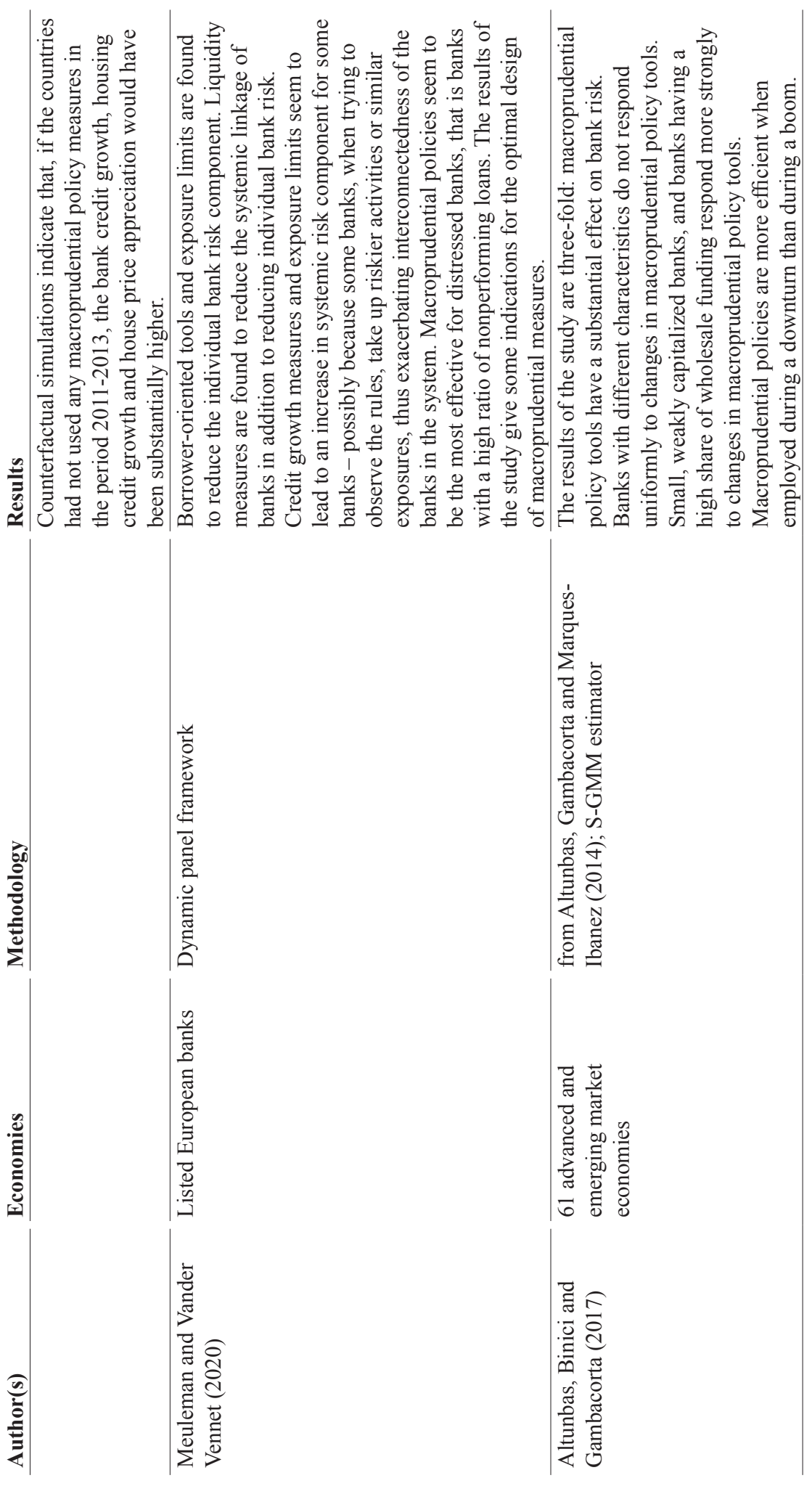

169

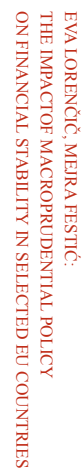


170
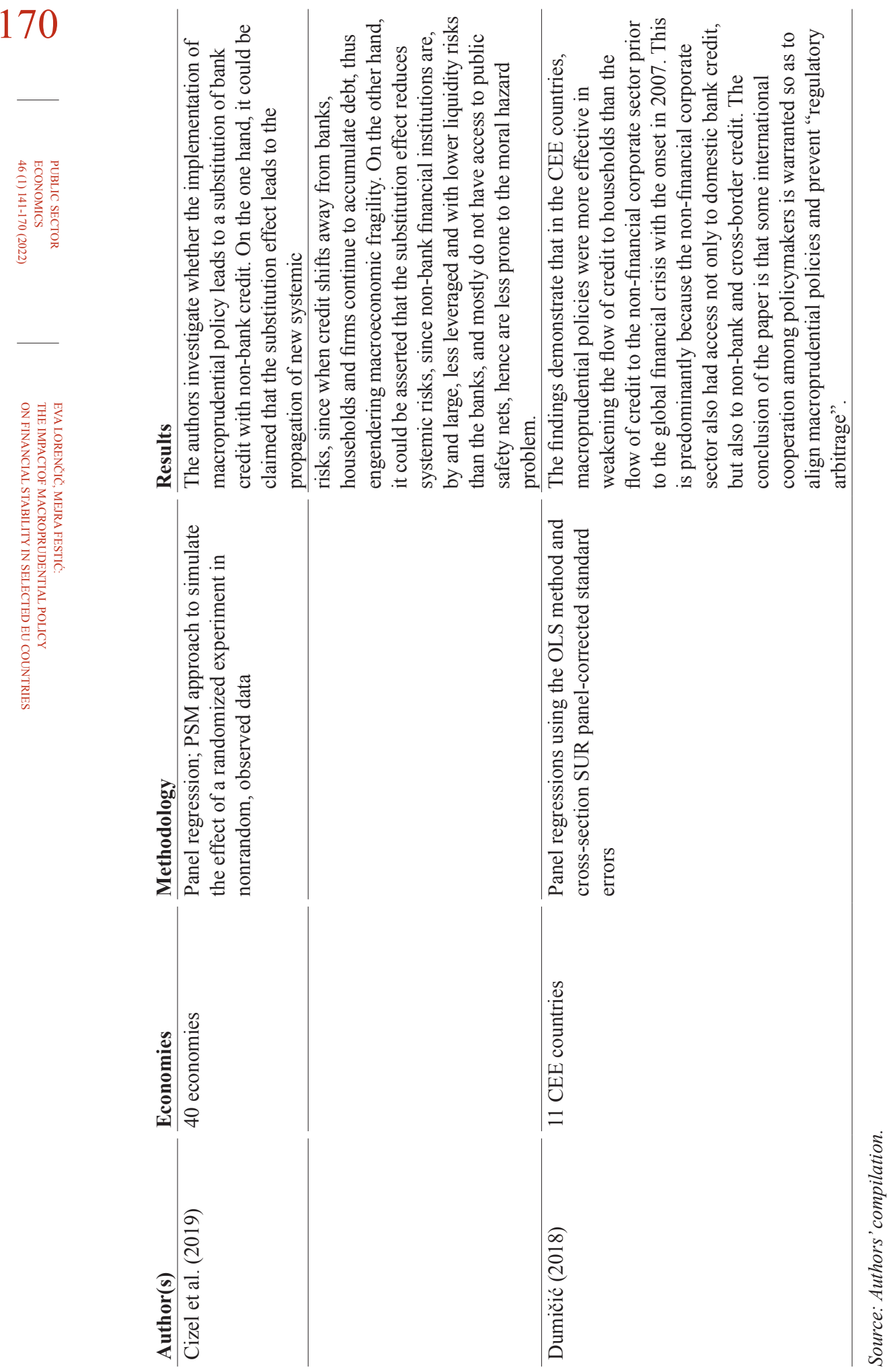